\title{
Variation within and among Blueberry Taxa in Flower Size and Shape
}

\author{
Paul M. Lyrene \\ Horticultural Sciences Department, University of Florida, Gainesville, FL 32611 \\ Additional index words. Vaccinium ashei, V. corymbosum, V. constablaei, V. elliottii, V. darrowi
}

\begin{abstract}
Variation was studied within and among five Vaccinium taxa for the flower parameters corolla length, corolla aperture diameter, stigma location relative to the apex of the corolla tube, position of the anthers relative to the stigma and to the apex of the corolla, and style length. The objective was to determine whether there was enough genetic variation to breed cultivars with flower shapes that might favor pollination by a wider range of bee species. The taxa studied were cultivated rabbiteye ( $V$. ashei Reade), cultivated southern highbush (mainly V. corymbosum L. with up to $30 \%$ introgression from $V$. darrowi Camp), $\mathrm{F}_{1}$ V. ashei $\mathrm{x}$ V. constablaei A. Gray hybrids, V. darrowi, and V. elliottii Chapm. Vaccinium elliottii flowers differed from all others in having short styles that were not exserted from the corolla tube. Vaccinium elliottii was also unusual in that the end of the anther tube extended nearly to the stigmatic surface. Vaccinium ashei corollas were longer and had smaller apertures than those of southern highbush, possibly making them less suitable for honeybee (Apis) pollination. For corolla length and aperture diameter, $\mathrm{F}_{1}$ V. ashei $\mathrm{x}$ V. constablaei hybrids were similar to southern highbush, indicating that $V$. constablaei introgression could be used to breed hexaploid cultivars with shorter, more open flowers. Large clone-to-clone variation within taxa for each flower characteristic indicates much potential for changing the shape of the blueberry flower by breeding, if the shape that maximizes fruit set can be determined.
\end{abstract}

North American cultivated blueberries-highbush (mainly Vaccinium corymbosum), lowbush (V. angustifolium Ait.), and rabbiteye (V.ashei)-are in Vaccinium section Cyanococcus (Camp, 1945; Luby et al., 1990). In this section, the petals are fused into a corolla tube and the flowers are cylindrical, urceolate, or campanulate. The anthers are poricidally dehiscent and do not readily shed pollen as a result of honeybee (Apis spp.) visits. North American native bee species that sonicate the flowers (Buchman, 1983) are efficient pollinators, but systems to manage these species to provide enough pollination in large blueberry plantations are not yet adequate. Poor fruit set, delayed ripening, and reduced berry size sometimes result from inadequate pollination in commercial blueberry fields. The problem has been particularly serious with rabbiteye blueberries in northern Florida (Lyrene and Crocker, 1983). Most bee species that co-occur with cultivated V. ashei do not visit its flowers because the adults emerge late in the spring following bloom, their tongues are too short to probe the flowers effectively (Cane and Payne, 1993), or the bees have a more attractive pollen and nectar source.

An ideal solution to the pollination problem in blueberries would be to develop cultivars that are fully self-compatible and copiously shed pollen directly onto their own stigmas without the aid of insects. Developing such cultivars is a feasible goal, but success will not come quickly, since many plant features unrelated to pollination also require the attention of blueberry breeders. Fortunately, important commercial benefits stemming from reduced pollination problems could be realized without achieving the perfect cultivar described above. Pollination problems could be alleviated by developing cultivars with improved self-fruitfulness, (either from enhanced parthenocarpy or from reduced self-incompatibility), more-abundant pollen production, anthers that discharge pollen more readily as a result of visits by honeybees and other nonsonicating bees, and flowers with shapes more conducive to pollen gathering by a wider array of bee species. Selection for

Received for publication 23 Dec. 1993. Accepted for publication 2 May 1994. University of Florida Journal series no. R-03579. The cost of publishing this paper was defrayed in part by the payment of page charges. Under postal regulations, this paper therefore must be hereby marked advertisement solely to indicate this fact. attractiveness to native pollinating insects should also improve fruitfulness.

The purpose of this study was to survey plant-to-plant variability in flower structure within and among five blueberry taxa to determine what genetic resources are available to breeders wishing to redesign the architecture of the blueberry flower.

\section{Materials and Methods}

Two experiments were conducted, one based on flowers gathered from a field planting in Gainesville, Fla., and the other based on flowers from potted plants growing in a greenhouse. The field experiment included twelve rabbiteye clones that were either cultivars or advanced selections from the Florida breeding program, seven southern highbush selections from the same breeding program, and five clones of $V$. elliottii, a diploid blueberry native in north Florida (and elsewhere in the southeastern United States) that has potential value in breeding southern highbush blueberries (Lyrene and Sherman, 1980; 1983). The five V. elliottii clones had been selected for good fruit characteristics from the forests of north Florida. Between 24 and 30 Mar. 1993, 10 well-developed flowers estimated to be 2 to 4 days past anthesis were collected from each plant and stored in $70 \%$ ethanol.

The following six structural features were measured for each flower. Corolla length, measured from the pedicel attachment point to the end of the corolla tube. The pedicel attachment point was chosen as the point from which to measure the corolla length even though the base of the corolla does not extend quite that far, because the actual position of the base of the corolla is hidden by the calyx cup. Corolla aperture, measured at the widest diameter (Fig. 1B). Corolla position vs. stigma, the distance from the tip of the stigma to the innermost sinuses (deepest indentations) of the corolla lobes. Negative values were assigned when the corolla did not reach to the stigma apex, i.e., the stigma extended outside of the corolla sinuses (Fig. 1D), and positive values were given when the corolla extended beyond the stigma (Fig. 1C). Anther length vs. corolla, the distance from the end of the longest anther to the sinuses of the corolla lobe. Negative values were recorded when the anthers did not reach the corolla sinuses. Anther length vs. 
stigma, the distance from the end of the longest anther to the apex of the stigma. Negative values were assigned when the anthers did not extend as far as the stigma apex (Fig. 1D). Style length, measured from the point of attachment at the ovary to the apex of the stigmatic surface. Except for the first two characteristics, all measurements were made using a $20 \times$ stereo microscope.

In the greenhouse experiment, fifteen advanced $V$. ashei selections from the Florida breeding program, sixteen southern highbush selections, nine $V$. ashei $\times$. constablaei $\mathrm{F}_{1}$ hybrids, four $V$. darrowi plants selected from the forest in Marion County, Fla., and two $V$. elliottii plants selected from the forest in the Florida panhandle were sampled. Five of the $V$. ashei clones and four of the southern highbush clones were present in the field and the greenhouse experiments; all other clones were unique to one or the other experiment. Except for NC1827 and NC1832, which were obtained from J.R. Ballington, Jr., North Carolina State Univ., Raleigh, the $\mathrm{F}_{1} V$. ashei $\mathrm{x}$. constablaei hybrids were produced in Florida by pollinating advanced $V$. ashei selections from the Florida breeding program with pollen from several $V$. constablaei selections obtained from the national Vaccinium germplasm repository in Corvallis, Ore. For the greenhouse experiment, plants were dug from the blueberry breeding nursery in Gainesville on 20 Dec. 1992. These were potted, chilled at 5C for $1300 \mathrm{~h}$, and then placed in a greenhouse on 12 Feb. 1993. Between 19 and 24 Mar. 1993, 10 flowers from each plant were harvested several days after anthesis and placed in $70 \%$ ethanol. Flower measurements were made as for the field experiment.

The data from each experiment were analyzed as follows. First, a separate analysis of variance was made for each taxon, with $n$ clones per taxon and 10 flowers per clone in a completely random analysis of variance. The F test for each analysis indicated whether there was significant clone-to-clone variation within each taxon. Next, for each trait, the mean value over 10 flowers was calculated for each clone. These means were then used in a completely random analysis of variance in which clone-to-clone variance within taxa was pooled and used to test the significance of the variation among taxa. Means of the taxa were then compared using pair-wise $t$ tests in which the denominator was calculated from the variance among clones within taxa.

\section{Results and Discussion}

There was much plant-to-plant variation within taxa for every flower characteristic measured. In addition, there were significant differences among taxa for most characteristics.

Vaccinium elliottii flowers differed from all others in that the stigmas were never exserted from the corolla tube (positive values for corolla length vs. stigma in Tables 1 and 2). This was apparently due to the short styles of $V$. elliottii, because the anthers of this species were in the normal position relative to the corolla apex but were in an abnormal position relative to the stigma; compared to the other species, the apex of the V. elliottii anther was unusually near the apex of the stigma. The anther-to-stigma distances were measured from anther apex to stigma apex. Vaccinium elliottii stigmas were $0.4 \mathrm{~mm}$ long. When this is taken into account, the end of the anther averaged only 0.3 to $0.5 \mathrm{~mm}$ from the nearest surface of the stigma. This close juxtaposition of the anther pores with the stigmatic surface would seem to increase the likelihood of self pollination in the $V$. elliottii flower. Whether the unique flower structure of $V$. elliottii evolved in response to a particular pollinating insect is not known.

Growers have frequently speculated that the rabbiteye blue-

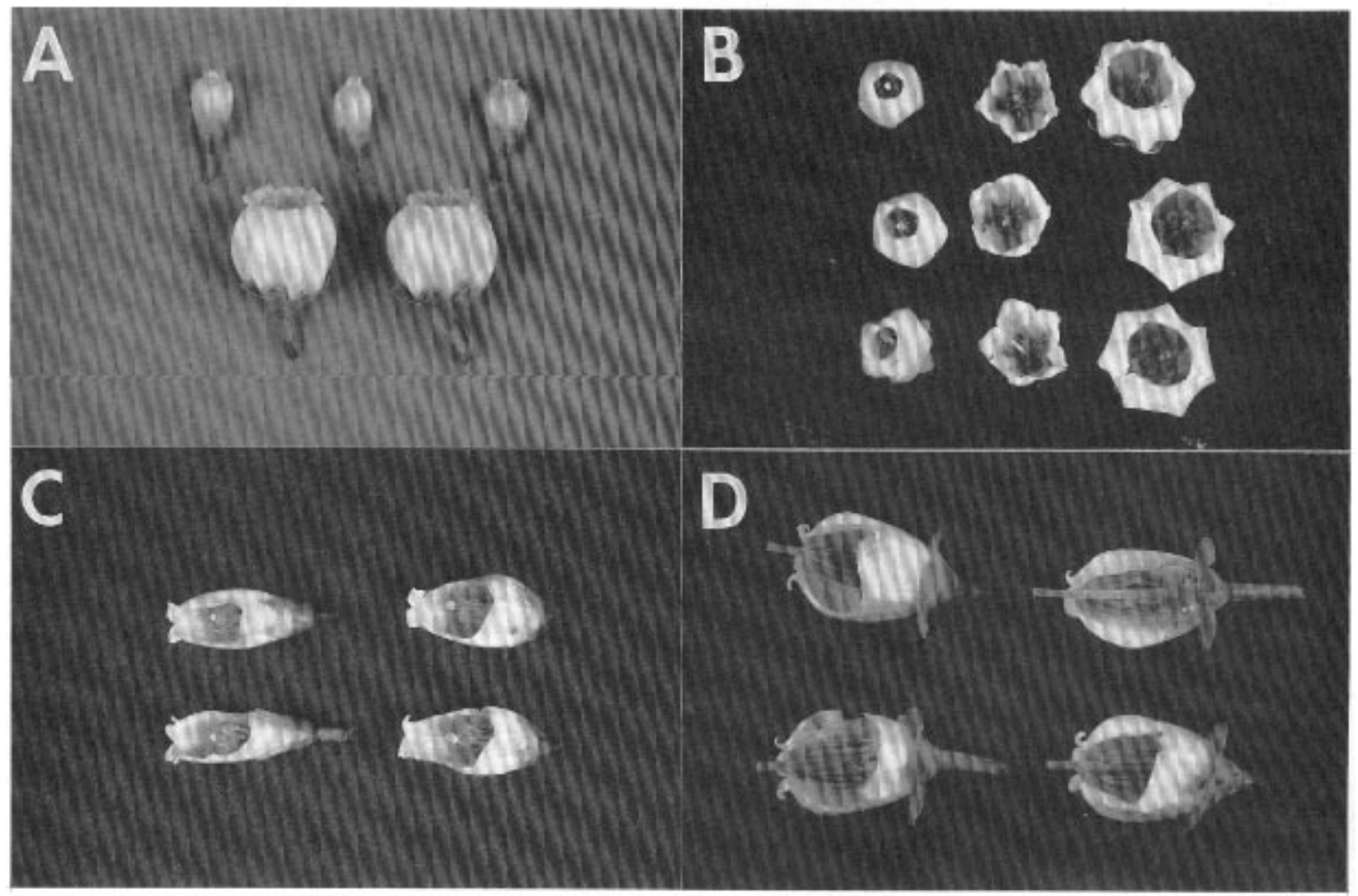

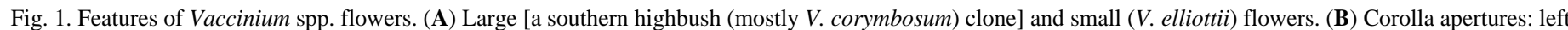

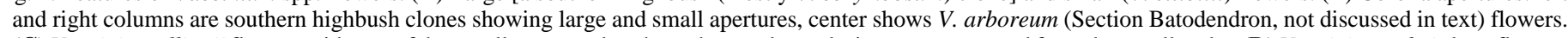

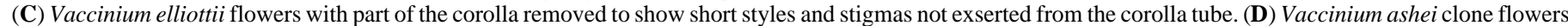
with stigmas exserted well beyond the end of the corolla tube. 
Table 1. Flower measurements for three blueberry taxa grown in the field in Gainesville, Fla.

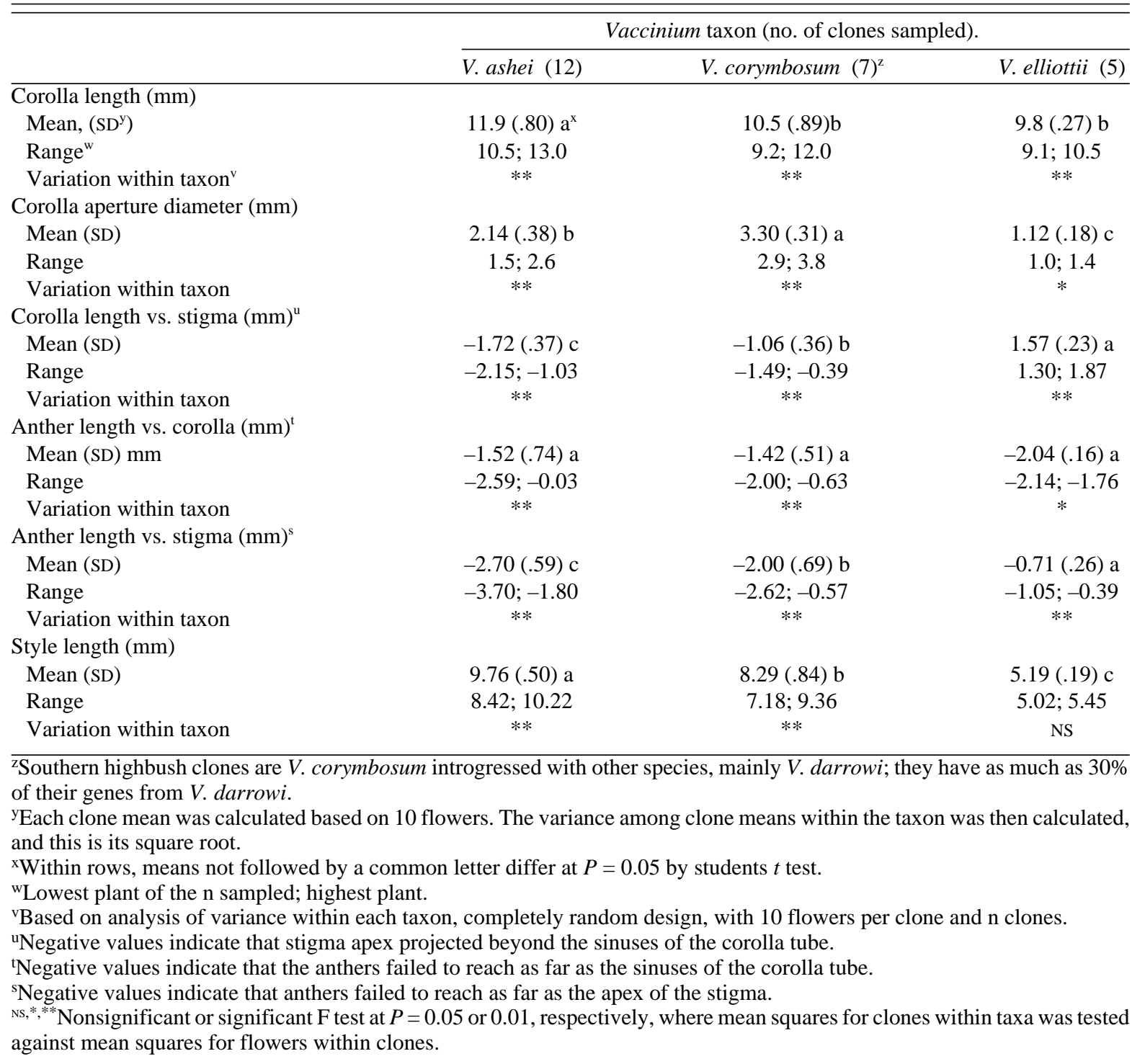

berry flower is less suitable for honeybee pollination than the highbush flower because it is longer and has a smaller corolla tube aperture. These differences in flower structure were confirmed in this study. Highbush flowers averaged only $88 \%$ as long as rabbiteye flowers for the field clones and only $85 \%$ as long for the greenhouse clones. The corolla aperture for the rabbiteye field clones averaged only $65 \%$ as wide as for the highbush field clones. For the greenhouse clones, the rabbiteye apertures averaged only $78 \%$ as wide. The long corolla tube and its narrow aperture might make it harder for honeybees to reach the nectar in the rabbiteye flower. If these floral features affect pollination success rates, it would seem relatively easy to improve the rabbiteye flower shape, since the clones were quite variable in this species, and the $\mathrm{F}_{1} V$. ashei $\times$ V. constablaei hybrids averaged as good or better than the highbush clones for both features (Table 2). Both of the diploid wild species, V. elliottii and $V$. darrowi, had flowers with very narrow corolla apertures compared to the cultivated highbush and rabbiteye clones. Whatever selection pressures have prevailed in the forests of north Florida have apparently not strongly favored wide corolla apertures.

Only one taxon, $V$. ashei $\times V$. constablaei $\mathrm{F}_{1}$ hybrids, stood out with respect to the anther position relative to the corolla apex
(Table 2). In these hybrids, the anthers were inserted less deeply into the corolla tube than was typical for the other taxa. One $V$. ashei plant, however, had anthers that came nearly to the apex of the corolla tube (Table 1).

The high clone-to-clone variation in most flower structural features indicates that redesigning the blueberry flower would not be difficult for the breeder. We have noticed that in segregating populations derived from crosses in which plants with large flowers (e.g., some highbush cultivars) (Fig. 1A) were crossed with plants with small flowers (e.g., V. darrowi and V. elliottii), plants can be found that are highly allometric for various flower parts, having, for example, very short corolla tubes with long styles or vice versa. Thus, selection after interspecific hybridization should be an efficient method for developing clones with anomalous flower architecture.

There have been few studies in blueberries of the relationship between flower shape and fruit set percent following visitation by various insect species. Such information, if available, would be useful to blueberry breeders, who can measure flower shape parameters for many test selections but cannot easily determine which of a large number of clones would set fruit well in large commercial plantings. 
Table 2. Flower measurements for five blueberry taxa grown in a greenhouse.

\begin{tabular}{|c|c|c|c|c|c|}
\hline & \multicolumn{5}{|c|}{ Vaccinium taxon (no. of clones sampled) } \\
\hline & V. ashei (15) & V. corymbosum $(16)^{\mathrm{z}}$ & $\begin{array}{c}\mathrm{F}_{1}: \text { V. ashei } \mathrm{x} \\
\text { V. constablaei }(9)\end{array}$ & V. darrowi (4) & V. elliottii (2) \\
\hline \multicolumn{6}{|l|}{ Corolla length (mm) } \\
\hline Mean $\left(\mathrm{SD}^{\mathrm{y}}\right)$ & $13.30(.88) \mathrm{a}^{\mathrm{x}}$ & $11.34(1.25) \mathrm{b}$ & $10.43(1.27) \mathrm{b}$ & $8.30(.47) \mathrm{c}$ & $8.40(.28) \mathrm{c}$ \\
\hline Range $^{w}$ & $12.2 ; 15.9$ & $8.8 ; 13.3$ & $8.0 ; 12.1$ & $8.0 ; 9.0$ & $8.2 ; 8.6$ \\
\hline Variation within taxon ${ }^{\mathrm{v}}$ & $* *$ & $* *$ & $* *$ & $* *$ & NS \\
\hline \multicolumn{6}{|c|}{ Corolla aperture diameter (mm) } \\
\hline Mean (SD) & $2.92(.54) b$ & $3.76(.78) \mathrm{a}$ & $3.62(.59) \mathrm{a}$ & $1.52(.46) \mathrm{c}$ & $1.20(.28) \mathrm{c}$ \\
\hline Range & $1.9 ; 3.9$ & $2.1 ; 4.7$ & $3.0 ; 4.4$ & $1.0 ; 2.0$ & $1.0 ; 1.4$ \\
\hline Variation within taxon & $* *$ & $* *$ & $* *$ & $* *$ & NS \\
\hline \multicolumn{6}{|l|}{ Corolla length vs. stigma } \\
\hline Mean & $-1.31(.66) \mathrm{a}$ & $-0.58(.68) b$ & $-1.25(.30) \mathrm{a}$ & $-0.89(.35) \mathrm{ab}$ & $1.07(.30) \mathrm{c}$ \\
\hline Range & $-2.38 ; 0.42$ & $-1.75 ; 0.72$ & $-1.78 ;-0.93$ & $-1.19 ;-0.45$ & $0.86 ; 1.28$ \\
\hline Variation within taxon & $* *$ & $* *$ & $* *$ & $* *$ & $* *$ \\
\hline \multicolumn{6}{|l|}{ Anther length vs. corolla } \\
\hline Mean & $-1.91(.72) \mathrm{a}$ & $-1.85(.51) \mathrm{a}$ & $-0.92(.42) \mathrm{b}$ & $-1.90(.54) \mathrm{a}$ & $-1.83(.10) \mathrm{a}$ \\
\hline Range & $-3.09 ;-0.63$ & $-2.71 ;-0.52$ & $-1.34 ;-0.07$ & $-2.35 ;-1.16$ & $-1.90 ;-1.76$ \\
\hline Variation within taxon & $* *$ & $* *$ & $* *$ & $* *$ & $*$ \\
\hline \multicolumn{6}{|l|}{ Anther length vs. stigma } \\
\hline Mean & $-2.65(.83) \mathrm{a}$ & $-2.24(.63) \mathrm{ab}$ & $-1.71(.41) b c$ & $-2.30(.53) \mathrm{ab}$ & $-0.94(.33) \mathrm{c}$ \\
\hline Range & $-3.89 ;-1.35$ & $-3.18 ;-1.22$ & $-2.12 ;-0.90$ & $-2.78 ;-1.54$ & $-1.17 ;-0.71$ \\
\hline Variation within taxon & $* *$ & $* *$ & $* *$ & $* *$ & \\
\hline \multicolumn{6}{|l|}{ Style length } \\
\hline Mean & $10.65(.72) \mathrm{a}$ & $8.77(.90) b$ & $8.31(1.13) b$ & $6.64(.45) \mathrm{c}$ & $5.31(.75) \mathrm{c}$ \\
\hline Range & $9.62 ; 12.22$ & $7.22 ; 10.84$ & $6.51 ; 9.65$ & $6.18 ; 7.12$ & $4.78 ; 5.84$ \\
\hline Variation within taxon & $* *$ & $* *$ & $* *$ & $* *$ & $* *$ \\
\hline
\end{tabular}

${ }^{\mathrm{z}}$ Southern highbush clones are $V$. corymbosum introgressed with other species, mainly $V$. darrowi; they have as much as $30 \%$ of their genes from $V$. darrowi.

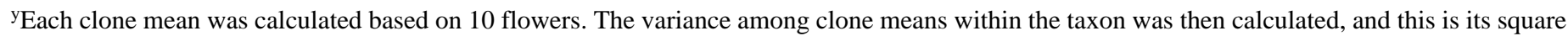
root.

${ }^{\mathrm{x}}$ Within rows, means not followed by a common letter differ at $P=0.05$ by students $t$ test.

${ }^{\mathrm{w}}$ Lowest plant of the $\mathrm{n}$ sampled; highest plant.

'Based on analysis of variance within each taxon, completely random design, with 10 flowers per clone and $\mathrm{n}$ clones.

Ns,*,** Nonsignificant or significant $\mathrm{F}$ test at $P=0.051$ or 0.01 , where mean squares for clones within taxa was tested against mean squares for flowers within clones.

In a study of 35 highbush blueberry cultivars and selections, Eck and Mainland (1971) found that high fruit set was associated with short, wide corollas, and a short distance between stigma and anther tip. They hypothesized that these flower characteristics might improve insect pollination.

Marucci (1965) found that 13 highbush blueberry cultivars varied greatly in their attractiveness to honeybees under field conditions in New Jersey, and that these differences were quite consistent from year to year. Some cultivars averaged 10 times more honeybee visits per minute than others. Cultivars that were most attractive to honeybees produced high berry yields; unattractive cultivars had low production.

According to Darlington and Janaki Ammal (1945), selection for short styles during domestication of tomatoes (Lycopersicon) and black currants (Ribes) helped develop inbreeding cultivars from outbreeding progenitors. Data from this study indicate that $V$. elliottii could be useful in breeding blueberry cultivars with short styles.

Improved flower shape can go only so far in improving blueberry fruit set in situations in which sonicating bees are not adequately abundant. Clones that copiously shed pollen of high viability and clones with increased self-fertility or parthenocarpy may also be needed to eliminate all pollination woes in commercial blueberry fields.

\section{Literature Cited}

Buchman, S.L. 1983. Buzz pollination in angiosperms, p. 73-113. In: C.E. Jones and R.J. Little (eds.). Handbook of experimental pollination biology. Van Nostrand Reinhold Co., New York.

Camp, W.H. 1945. The North American blueberries with notes on the other groups of Vacciniaceae. Brittonia 5:203-275.

Cane, J.H. and J.A. Payne. 1993. Regional, annual, and seasonal variation in pollinator guilds: Intrinsic traits of bees (Hymenoptera: Apoidea) underlie their patterns of abundance at Vaccinium ashei (Ericaceae). Ann. Entomol. Soc. Amer. 86:577-588.

Darlington, C.D. and E.K. Janaki Ammal. 1945. Chromosome atlas of cultivated plants. George Allen and Unwin Ltd., London.

Eck, Paul and C.M. Mainland. 1971. Highbush blueberry fruit set in relation to flower morphology. HortScience 6:494-495.

Luby, J.L, J.R. Ballington, A.D. Draper, K. Pliszka, and M.E. Austin. 1990. Blueberries and cranberries (Vaccinium) 2 p. 393-456. In: J.N. Moore and J.R. Ballington, Jr. (eds.). Genetic resources of temperate fruit and nut crops. vol. 1. Intl. Soc. Hort. Sci., Wageningen, The Netherlands.

Lyrene, P.M. and W.B. Sherman. 1980. Horticultural characteristics of native Vaccinium darrowi, V. elliottii, V. fuscatum, and V. myrsinites in Alachua County, Florida. J. Amer. Soc. Hort. Sci. 105:393-396.

Lyrene, P.M. and W.B. Sherman. 1983. Mitotic instability and 2n gamete production in Vaccinium corymbosum X V. elliottii hybrids. J. Amer. Soc. Hort. Sci. 108:339-342.

Lyrene,P.M. and T.E. Crocker, 1983. Poor fruit set on rabbiteye blueberries after mild winters: possible causes and remedies. Proc. Fla. State Hort. Soc. 96:195-197.

Marucci, P.E. 1965. Blueberry pollination. Proc. 33rd Annu. Blueberry Open House. New Jersey Agr. Expt. Sta., New Brunswick. p. 16-19. 